Memorializing the Middle Classes in Medieval and Renaissance Europe 
STUDIES IN MEDIEVAL AND EARLY MODERN CULTURE

Medieval Institute Publications is a program of The Medieval Institute, College of Arts and Sciences 


\section{Memorializing the Middle Classes in Medieval and Renaissance Europe}

Edited by Anne Leader

Studies in Medieval and Early Modern Culture

MEDIEVAL INSTITUTE PUBLICATIONS

Western Michigan University

Kalamazoo 
Copyright (c) 2018 Walter de Gruyter GmbH, Berlin/Boston

\section{Library of Congress Cataloging-in-Publication Data are available from the Library of Congress.}

ISBN: 9781580443456

eISBN: 9781580443463

All rights reserved. Without limiting the rights under copyright reserved above, no part of this book may be reproduced, stored in, or introduced into a retrieval system, or transmitted, in any form, or by any means (electronic, mechanical, photocopying, recording, or otherwise) without the written permission of both the copyright owner and the author of the book.

Every effort has been made to obtain permission to use all copyrighted illustrations reproduced in this book. Nonetheless, whosoever believes to have rights to this material is advised to contact the publisher. 